\title{
DESIGN AND SYNTHESIS OF HIGHLY POTENT AND SPECIFIC DYNORPHIN DERIVATIVES FOR AFFINITY LABELING OF $K$ OPIOID RECEPTORS
}

\section{Rei MATSUEDA, ${ }^{*}, \mathbf{a}$ Katsuo KOIKE, band Issei TAKAYANAGI $^{\mathrm{b}}$}

New Lead Research Laboratories Sankyo Co. Ltd., a Shinagawa-ku, Tokyo 140 and School of Pharmaceutical Sciences, Toho

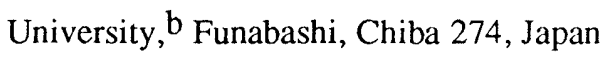

Dynorphin A derivatives containing S-(3-nitro-2-pyridinesulfenyl)-cysteine(Cys(Npys)) were designed and synthesized for affinity labeling of $\kappa$ opioid receptors. Derivatives with Cys(Npys) residue at the 8 position were highly potent and specific to $\kappa$ receptors and bound to receptors through disulfide bond formation.

KEYWORDS dynorphin; affinity labeling; disulfide bond; $\kappa$-receptor; solid phase synthesis

Dynorphin $\mathrm{A}$ is a 17 amino acid peptide containing the sequence of Leu-enkephalin at its $\mathrm{N}$-terminal ; it is the most potent opioid peptide as $\mathrm{K}$ receptor selective agonist. Many dynorphin analogs were reported, and the structure-function relationships have been reviewed. ${ }^{2)}$ Sequential removal of C-terminal amino acids of dynorphin A established that dynorphin $\mathrm{A}(1-13)$ has almost the same potency as dynorphin A and that the basic Arg-7, Lys-11, and Lys-13 are required for high $\mathrm{K}$ selectivity and potency.

Smith and Simon have suggested that the opioid receptor contains a thiol function in its binding site, ${ }^{3)}$ and we have already succeeded in developing $\mu$-receptor selective $\left[\mathrm{D}-\mathrm{Ala}^{2}, \mathrm{Leu}\left(\mathrm{CH}_{2} \mathrm{SNpys}\right)^{5}\right]$ enkephalin $\left.{ }^{4}\right)$ and $\delta$-receptor selective [D-Ala ${ }^{2}$, $\mathrm{Leu}^{5}$ ]enkephalyl-Cys(Npys), ${ }^{6)}$ which covalently linked to their receptors through disulfide bond formation and exhibited high affinity and selectivity for $\mu$ and $\delta$ receptors, respectively.

Based on these findings, we postulated that affinity labeling of $\kappa$ receptors would be possible if we could position a $S$ Npys group properly in the dynorphin A(1-13) sequence. Thus, we have designed dynorphin A(1-13) analogs containing Cys(Npys) residue at the 6 or 8 position and Arg- 7 for $\kappa$-selectivity in the "address code" that was proposed by Goldstein $e t$ $a l .7)$ to direct the peptide to the $\mathrm{K}$ receptor, as depicted in Fig. 1.

dynorphin $\mathrm{A}(1-13)$

(1)

(2)

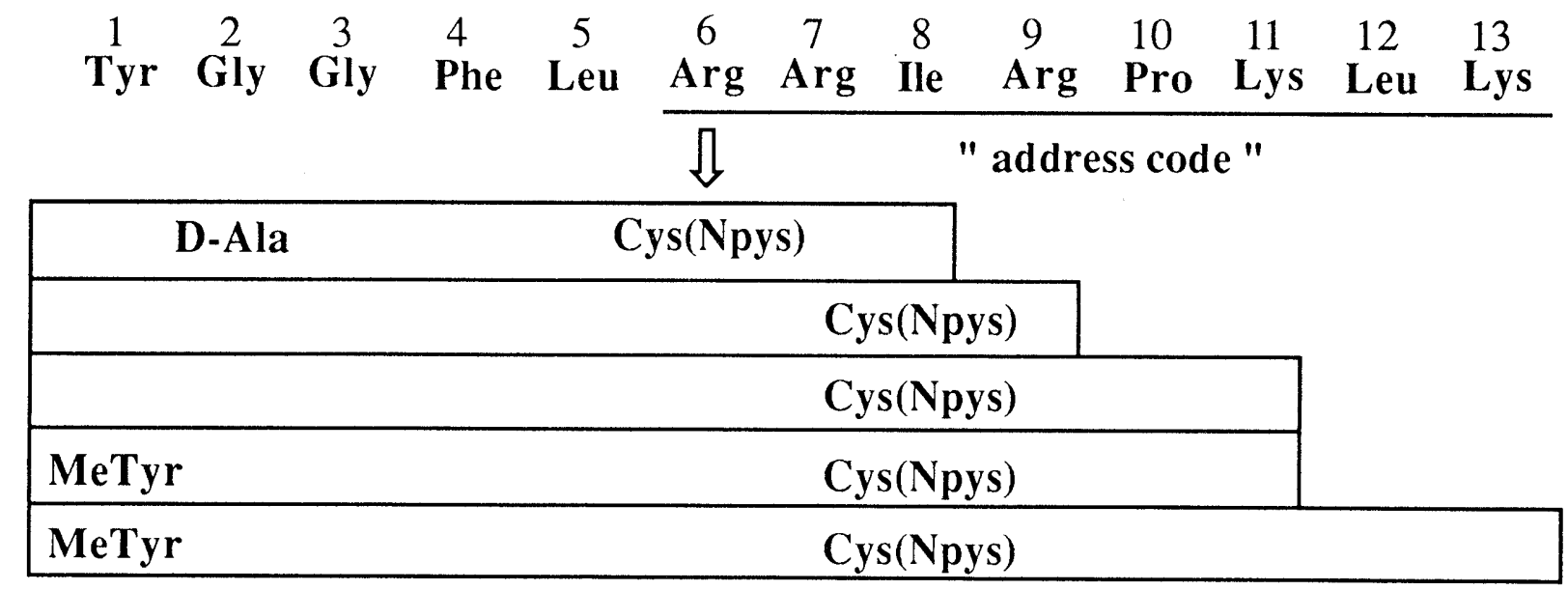

Fig. 1. Design of Dynorphin A(1-13) Analogs for Affinity Labeling of $\kappa-$ Receptor 
All the peptides were prepared by the solid phase method using Boc-amino acids according to the general procedures of Stewart and Young. ${ }^{8)}$ The following side chain protecting groups were used: 2-bromobenzyloxycarbonyl(Br-Z) for Tyr, 3nitro-2-pyridinesulfenyl(Npys) for Cys, tosyl(Tos) for Arg, and 2-chlorobenzyloxycarbonyl(CL-Z) for Lys. In a typical experiment, starting from $2 \mathrm{~g}$ of benzhydrylamine resin ( $2 \%$ cross-linked polystyrene-divinylbenzene copolymer, containing $1.44 \mathrm{mmol}$ of the amine component), the Boc derivatives of $\operatorname{Arg}(\mathrm{Tos}), \mathrm{Cys}(\mathrm{Npys}), \operatorname{Arg}(\mathrm{Tos}), \operatorname{Arg}(\mathrm{Tos})$, Leu, Phe, Gly, Gly, and $\operatorname{Tyr}(\mathrm{Br}-\mathrm{Z})$ were coupled successively with 3 eq. of dicyclohexylcarbodiimide and 6 eq. of 1-hydroxybenzotriazole, using 3 eq. of each amino acid in DMF for 2-5 h. Boc group was removed with $50 \%$ TFA in $\mathrm{CH}_{2} \mathrm{Cl}_{2}$ and the coupling efficiency was judged by the method of Kaiser et al. $\left.{ }^{9}\right)$ The completed peptide resin was dried and treated with $20 \mathrm{ml}$ of HF containing 2 $\mathrm{ml}$ of anisole for $30 \mathrm{~min}$ at $0^{\circ} \mathrm{C}$. After removal of the $\mathrm{HF}$, the resin was washed with several portions of diethyl ether and the liberated peptide was extracted twice with $30 \mathrm{ml}$ of TFA. The extract was condensed and the residue was triturated with diethyl ether. The crude product was purified with Sephadex LH-20 equilibrated and eluted with MeOH, followed by HPLC on a C-18 column using a linear gradient of $0.1 \%$ TFA in water to $50 \%$ acetonitrile in water containing $0.1 \%$ TFA.

Table.I. Physical Properties and Biological Activities of Synthetic Dynorphin Derivatives

\begin{tabular}{|c|c|c|c|}
\hline \multirow[t]{2}{*}{ Synthetic peptides a) } & \multirow[t]{2}{*}{$\begin{array}{c}\mathrm{mp} /{ }^{\circ} \mathrm{C} \\
\left([\alpha]_{\mathrm{D}} 22 /^{\circ}, c \quad 0.2, \text { solvent }\right)\end{array}$} & \multicolumn{2}{|c|}{$\begin{array}{l}\left.\text { Mechanical response }{ }^{b}\right) \\
\left.\mathrm{pD}_{2} \text { value(- } \log \mathrm{ED}_{50}\right)\end{array}$} \\
\hline & & GPI c) & RVD d) \\
\hline (1) H-Tyr-D-Ala-Gly-Phe-Leu-Cys(Npys)-Arg- & $214-218$ & $7.07 \pm 0.02$ & \\
\hline Ile-OH$\cdot 2 \mathrm{TFA} \cdot 2 \mathrm{H}_{2} \mathrm{O}$ & $(-38.6, \mathrm{DMF})$ & & \\
\hline $\begin{array}{l}\text { (2) } \mathrm{H} \text {-Tyr-Gly-Gly-Phe-Leu-Arg-Arg-Cys(Npys)- } \\
\text { Arg-NH } \mathrm{NH}_{2} \cdot 4 \mathrm{TFA} \cdot 2 \mathrm{H}_{2} \mathrm{O}\end{array}$ & $\begin{array}{c}216-220 \\
(-61.0, \mathrm{MeOH})\end{array}$ & $11.41 \pm 0.17$ & $11.57 \pm 0.09$ \\
\hline $\begin{array}{l}\text { (3) H-Tyr-Gly-Gly-Phe-Leu-Arg-Arg-Cys(Npys)- } \\
\text { Arg-Pro-Lys- } \mathrm{NH}_{2} \cdot 5 \mathrm{TFA} \cdot 2 \mathrm{H}_{2} \mathrm{O}\end{array}$ & $\begin{array}{c}210-215 \\
(-57.0, \mathrm{MeOH})\end{array}$ & $8.23 \pm 0.06$ & \\
\hline $\begin{array}{l}\text { (4) H-MeTyr-Gly-Gly-Phe-Leu-Arg-Arg- } \\
\text { Cys(Npys)-Arg-Pro-Lys-NH } 2 \cdot 5 \mathrm{TFA} \cdot 2 \mathrm{H}_{2} \mathrm{O}\end{array}$ & $\begin{array}{c}215-218 \\
(-48.8, \mathrm{MeOH})\end{array}$ & $8.45 \pm 0.08$ & \\
\hline $\begin{array}{l}\text { (5) H-MeTyr-Gly-Gly-Phe-Leu-Arg-Arg-Cys(Npys)- } \\
\text { Arg-Pro-Lys-Leu-Lys-NH } 2 \text {-6TFA-2 } \mathrm{H}_{2} \mathrm{O}\end{array}$ & $\begin{array}{c}221-225 \\
(-53.8, \mathrm{MeOH})\end{array}$ & $8.53 \pm 0.12$ & \\
\hline Dynorphin $A(1-13)$ & & $7.34 \pm 0.05$ & $6.43 \pm 0.05$ \\
\hline Nalorphine-epoxide ${ }^{5)}$ & & $7.39 \pm 0.08$ & $6.16 \pm 0.12$ \\
\hline $\mathrm{KT}-90 \mathrm{e})$ & & $8.49 \pm 0.08$ & $8.15 \pm 0.08$ \\
\hline
\end{tabular}

a) All the compounds were fully characterized by elemental and amino acid analyses.

b) Mechanical response tests were carried out using strips of GPI and RVD field-stimulated $(0.1 \mathrm{~ms}, 0.1 \mathrm{~Hz})$ in Krebs-Ringer solution. Tests were repeated 6 times for each compound to calculate the concentration required to produce $50 \%$ of the maximum response to the compound $\left(\mathrm{ED}_{50}\right)$, and the values were expressed as $\mathrm{pD}_{2}$, i.e., negative logarithm of $\mathrm{ED}_{50}$.

c) GPI : Guinea-pig ileum. d) RVD : Rabbit vas deferens. e) KT-90 : 3-O-Acetyl-6ß-(acetylthio)-N-(cyclopropylmethyl)-6deoxynormorphine. ${ }^{10)}$

The yellow fractions showing a single spot on TLC were pooled and evaporated. Pure H-Tyr-Gly-Gly-Phe-Leu-ArgArg-Cys(Npys)-Arg- $\mathrm{NH}_{2} \cdot 4 \mathrm{TFA} \cdot 2 \mathrm{H}_{2} \mathrm{O}$ was obtained by precipitation from $\mathrm{MeOH}$-diethyl ether; $1.31 \mathrm{~g}, 52.2 \%$ yield from the initial benzhydrylamine resin: mp $216-220^{\circ} \mathrm{C}(\mathrm{dec}),[\alpha]_{\mathrm{D}}{ }^{22}-61.0^{\circ}(\mathrm{c} 0.2 \mathrm{MeOH})$. Anal. Calcd for $\mathrm{C}_{62} \mathrm{~F}_{12} \mathrm{H}_{89} \mathrm{~N}_{21} \mathrm{O}_{22} \mathrm{~S}_{2}$ : C,42.01;F, 12.86; H, 5.06; N, 16.60; S, 3.62. Found: C, 41.92; F, 12.77; H, 5.22; N, 16.48; S, 3.36. Amino acid ratios

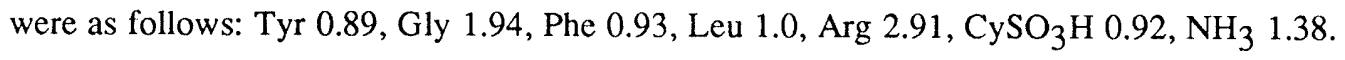


The synthetic peptides were tested in isolated organ preparations. They and dynorphin $A(1-13)$, reference drug, inhibited, in a concentration-dependent manner, the twitch response to field stimulation of the longitudinal muscle of guineapig ileum (GPI), which contains both $\mu$ and $\kappa$ receptors, and rabbit vas deferens (RVD), which contains only $\kappa$ receptors. The results are shown in Table I. Compound 2, which has Cys(Npys) residue at the 8 position of dynorphin A(1-9), was the most potent and was 2,600 times as potent as KT-90, a potent $K$ agonist. ${ }^{10)}$. The $\mathrm{pD}_{2}$ values in GPI and RVD were almost the same. The concentration-response curve of nalorphine-epoxide ${ }^{5)}$, a selective $\kappa$ receptor agonist, in the electrical stimulated RVD was inhibited by a 30-min treatment with the compound $2\left(1 \times 10^{-7} \mathrm{M}\right)$. This inhibitory activity of compound 2 did not alter even after the RVD tissue was allowed to equilibrate for $3 \mathrm{~h}$, with repeated washing every $10 \mathrm{~min}$, but it was completely abolished by treatment with dithiothreitol $\left(3 \times 10^{-3} \mathrm{M}\right)$, a disulfide reducing agent. Its specificity to $\kappa$ receptors was further confirmed by radio-ligand receptor binding assay using synaptosomal fractions of rat brain. The binding of $\left[{ }^{3} \mathrm{H}\right] \mathrm{U}$ $69593,{ }^{11)}$ a $\mathrm{K}$ receptor selective ligand, was completely displaced by simultaneous addition of an increasing concentration of compound 2, and the decrease of $\left[{ }^{3} \mathrm{H}\right] \mathrm{U}-69593$ binding did not recover by washing with buffer for $6 \mathrm{hr}$. However, this decrease was also recovered by treatment with $2 \times 10^{-3} \mathrm{M}$ of dithiothreitol. These results indicate that compound 2 is a $\mathrm{K}$ agonist with high intrinsic activity and bound to $\mathrm{K}$ receptors through disulfide bond formation. With using compound 2 , it was also found that rat brain preparations had a large population of spare receptors. ${ }^{12)}$

The affinity labeling approach encompassing the use of Npys group bound to ligand mimetics is versatile for developing specific labeling ligands for receptors with thiol functions. These synthetic Npys-dynorphin derivatives show promise in clarifying the $\mathrm{\kappa}$ receptor mechanism.

\section{REFERENCES AND NOTES}

1) The abbreviations by the IUPAC-IUB : J. Biol. Chem., 247, 977 (1972) and the following abbreviations are used : Boc=tbutyloxycarbonyl, TFA=trifluoroacetic acid, DMF=dimethylformamide, Npys=3-nitro- 2-pyridinesulfenyl.

2) V. J. Hruby and C. A. Gehrig, Med. Res. Rev., 9, 343 (1989).

3) J. R. Smith and E. J. Simon, Proc. Natl. Acad. Sci., U.S.A., 77, 281 (1980).

4) H. Kodama, Y. Shimohigashi, T. Ogasawara, T. Koshizaka, M. Kurono, R. Matsueda, K. Soejima, M. Kondo, and K. Yagi, Biochem. Int., 19, 1159 (1989).

5) F. Konno, C. Kobayashi, R. Morimoto, I. Takayanagi, N. Cho, and M. Hirobe, Arch. Int. Pharmacodyn. Ther. 282, 219 (1986).

6) R. Matsueda, T. Yasunaga, H. Kodama, M. Kondo, T. Costa, and Y. Shimohigashi, Chem. Lett., 1259 (1992).

7) A. Goldstein, " Molecular Genetic Neuroscience," eds. by F. O. Schmidt, S. J. Bird, and F. E. Bloom, Raven Press, New York, 1982, pp . 249-262.

8) J. M. Stewart and J. D. Young, " Solid Phase Peptide Synthesis," Pierce Chemical Company, Rockford, Illinois (1984).

9) E. Kaiser, R. L. Colescott, C. D. Bossinger, and P. I. Cook, Anal. Biochem., 34, 595 (1970).

10) I. Takayanagi, N. Goromatsu, K. Koike, F. Konno, T. Mori, M. Yoshida, and K. Kanematsu, Gen. Pharmacol., 21, 541 (1990).

11) $(5 \alpha, 7 \alpha, 8 \beta)-(+)-\mathrm{N}$-methyl-N-(7-(1-pyrolidinyl)-1-oxaspiro(4,5)dec-8-yl)benzeneacetamide (specific activity: $2146.0 \mathrm{GBq} /$ mmol) was perchased from New England Nuclear (Boston, USA).

12) K. Koike, I. Takayanagi, Y. Hirakura, and R. Matsueda, Arch. Int. Pharmacodyn. Ther., 313, 33 (1991). 